Archives of Agriculture and Environmental Science

\title{
Assessment of morphological and nutritional attributes of two varieties of Ipomoea batatas (L.) utilized in Nigeria
}

\author{
C.V. Ilodibia ${ }^{1^{*} \text { (D) , C.U. Arubalueze }}{ }^{2}$, S.N. Udearoh ${ }^{2}$, B.I. Okafor ${ }^{3}$ and C. Agbanusi ${ }^{1}$ \\ ${ }^{1}$ Department of Botany, Nnamdi Azikiwe University, P.M.B 5025, Awka, Anambra State, NIGERIA \\ ${ }^{2}$ Department of Agricultural Education, Nwafor Orizu College of Education Nsugbe, Anambra State, NIGERIA \\ ${ }^{3}$ Department of Biology, Federal College of Education (Technical) Umunze, Anambra State, NIGERIA \\ "Corresponding author's E-mail: chinyereokafor206@yahoo.com
}

\section{ARTICLE HISTORY}

Received: 19 November 2018

Revised received: 27 November 2018

Accepted: 30 November 2018

\begin{abstract}
Morphological and nutritional studies were carried out on various parts of the two varieties of Ipomoea batatas (white fleshed TIS 87/0087 and orange fleshed UMUSPO/3) to determine their morphological and nutritional characteristics using standard techniques. Analysis of variance was employed for data analysis. Result revealed that the two varieties had similar qualitative morphological features but showed variation in their length, breadth, colour and girth. The result of the proximate analysis revealed that the nutrients were present in all the parts of the two varieties investigated but in varied proportions. Protein, fat and ash were highest in the leaves of both varieties when compared to other parts $(12.13 \pm 0.20 \mathrm{mg} / 100 \mathrm{~g}$, $3.92 \pm 0.14 \mathrm{mg} / 100 \mathrm{~g}$ and $2.85 \pm 0.06 \mathrm{mg} / 100 \mathrm{~g}$ of $\mathrm{l}$. batatas respectively. Moisture and carbohydrate were highest in the tubers of both varieties when compared to other parts $(10.73 \pm 0.22 \mathrm{mg} / 100 \mathrm{~g}$ and $81.22 \pm 3.80 \mathrm{mg} / 100 \mathrm{~g})$ respectively while crude fiber was highest in the stem of the two varieties when compared to other parts $(26.15 \pm 0.29 \mathrm{mg} / 100 \mathrm{~g})$. Data obtained indicated that these parts of the two varieties contained appreciable amount of nutrients which could be included in diets to supplement our daily nutrient needs and animal feed. Apart from the tuber eaten by our people, other parts of the plant should also be used as food. Overall data could be a viable tool for sweet potato breeding as an improvement in sweet potato production. Morphological characteristics observed were similar indicating that the two varieties are phyllogenetically related. The data could also be used to enhance proper taxonomic characterization and identification of the species I. batatas.
\end{abstract}

(C)2018 Agriculture and Environmental Science Academy

Citation of this article: Ilodibia, C.V., Arubalueze, C.U., Udearoh, S.N., Okafor, B.I. and Agbanusi, C. (2018). Assessment of morphological and nutritional attributes of two varieties of Ipomoea batatas (L.) utilized in Nigeria. Archives of Agriculture and Environmental Science, 3(4): 394-398, https://dx.doi.org/10.26832/24566632.2018.0304011

INTRODUCTION

Sweet potato (Ipomoea batatas (L.) Lam., a dicotyledonous plant, belongs to the Convolvulaceae or morning glory family (Jones, 1965). This family consists of 45 genera and about 1650 species. Convolvulaceae is dominated by twinning or climbing woody or herbaceous plants that often have heart-shaped leaves and funnel-shaped flowers (Austin, 1977). The genus Ipomoea with approximately 500 - 600 species comprises the largest number of species within the Convolvulaceae (Austin and Huaman, 1996). It occurs in the tropics although some species also reach temperate zones (Cao et al., 2005). The species of this genus are mainly distributed throughout the South and Central America countries, and Tropical Africa territories (Austin and Huaman, 1996). The genus Ipomoea since time immemorial have been in continuous use for different purposes such as nutritional, medicinal, ritual, and cultural, But only I. batatas is economically important as food (Austin and Huaman, 1996).

Sweet potato (I. batatas Lam.) is a perennial plant, although it is typically cultivated as an annual crop (Janssens, 2001). It was described as the seventh most important food crop in the world (Bhattiprolu, 2000; Okorie and Onyeneke, 2012; Adepoju and Adejumo, 2015). It is an herbaceous creeping plant with smooth, lightly moderate green leaves sometimes with a considerable amount of purple pigmentation especially along its veins (Longe, 1986). The roots are adventitious, mostly located within the top $25 \mathrm{~cm}$ of the soil (Heuzé et al., 2015). Some of the roots produce elongated starchy tubers. Tuber flesh colour can be white, yellow, orange and purple while skin colour can be red, purple, and brown or white (Heuzé et al., 2015; Woolfe, 1992). 
The soft-fleshed varieties are sweet and have orange flesh and are often called yams (Parle and Monika, 2015). The firm-fleshed varieties have light orange, yellow, or even white flesh and can be stored for longer periods (Parle and Monika, 2015). Sweet potato is valued for its short growing period of about 3-4 months, high nutritional content and its sweetness (Adepoju and Adejumo, 2015). Sweet potato is considered as an important food security crop, especially in Nigeria (Adepoju and Adejumo, 2015) and is also identified as the least expensive, year round source of dietary vitamin A, especially the orangefleshed type among the poor (Okorie and Onyeneke, 2012). Sweet potatoes are among the major tropical staple foods utilized as food as well as livestock feed all over the world (Dzomeku et al., 2007). In the tropics, the fresh roots are commonly boiled, fried or roasted and eaten as a carbohydrate constituent of the diet (Zuraida, 2003). In parts of East Africa, tubers are sometimes sliced and sun-dried to produce chips, which are later ground into flour (Adepoju and Adejumo, 2015). In the Northern part of Nigeria, a garri-like product from sweet potato has been produced and evaluated; it is found to be of high nutritional value (Kure et al., 2012). Sweet potatoes are rich source of energy, antioxidants and vitamins (especially C) as well as carotenoids (Wakjira et al., 2011; Woolfe, 1992). They are also an excellent source of fibre and minerals, which are important in reducing blood cholesterol and aid digestion (Effah-Manu et al., 2013; Chukwu et al., 2012). The leaves are used as leafy vegetable as well as good fodder value and much more industrial value. Sweet potatoes are packed with nutrition. They are a great source of minerals such as manganese, folate, copper, and iron (Effah-Manu et al., 2013; Chukwu et al., 2012).

Despite the nutritional importance of this species, it is still poorly utilized in some part of the world especially in South eastern Nigeria where the populace are unaware of the high nutritional value of its other parts (leaf and stem), they grow sweet potatoes, wait for the storage roots to mature, harvest and discard the leaves or serve them as animal feed with few farmers consuming the harvested tops (leaves). In view of this, this study was aimed at evaluating the morphological and nutritional potentials of various parts of the two varieties of Ipomoea batatas (white fleshed TIS 87/0087 and orange fleshed UMUSPO/3) mostly consumed by our people.

\section{MATERIALS AND METHODS}

\section{Area of study and collection and identification of plants}

The experiments were carried out at the C.E.C Analytical Laboratory Service National Root Crops Research Institute, Umudike $\left(05^{\circ} 29^{1} \mathrm{~N}, 0732^{1} \mathrm{E}\right.$ and altitude $122 \mathrm{~m}$ a.s.l.), Abia state. The two varieties of sweet potato (white and orange fleshed) used in this work were collected between May- June 2016 from National Root Crops Research Institute (NRCRI), Umudike. The samples collected were properly identified by a curator in the institute.

Morphological study

Observations on vegetative characteristics were studied using samples collected from mature plant. A meter rule was used to measure the length, breadth dimension of leaves, flower and other parts. Other materials used include cardboard sheet and a camera. Photographs of the salient morphological features were taken. (This is as outlined by llodibia et al., 2017).

\section{Preparation of plant material}

The various parts of the two varieties of sweet potato used for this study were harvested fresh, the leaves, stem and tubers were separated and washed with clean cold tap water, oven dried and ground into a fine powder using an electric grinder.

\section{Nutritional analysis}

The following materials were used: Desiccators, muffle furnace, spectrometer, silica dish, Kjeldahl flask, funnel, soxhlet apparatus, filter paper, thimble, electric oven, grinder, retort stand, test tube, and test tube rack, crucible, weighing balance, Petri dish. The chemicals used include: Tetrahydrosulphate (vi) acid, Boric acid indicator solution, Sodium hydroxide, Hydrochloric Acid, petroleum ether, potassium hydroxide, Acetone, phenolphthalein indicator, Ammonia, Dithezone solution, carbon tetrachloride, hydroquinoline, phenonthroline, Vanado Molybidic acid, selenium oxide. Nutritional (carbohydrate, ash, protein, crude fat, crude fibre and moisture) analysis was carried out to ascertain the nutrient compositions present in the plant extracts. These were done using the standard methods described by Association of Official Analytical Chemist (AOAC, 2005).

\section{Statistical analysis}

Results were presented in mean \pm standard deviation and were subjected to analysis of variance (ANOVA) using Duncan's Multiple Range Test (DMRT) at 5\% probability to separate the treatments. Difference in mean value were considered significant at $\mathrm{P}<.05$.

\section{RESULTS AND DISCUSSION}

The results of the study are shown in Figures 1- 6 (a-f) and Table 1-2.

\section{Morphological studies}

Observations on the morphology of two varieties of Ipomoea batatas (Table 1 and Figures 1 (a-f) showed that the White fleshed (TIS 87/0087) variety is herbaceous and extremely spreading in habit, The phyllotaxy is Alternate; the leaves are 10.60 - $14.30 \mathrm{~cm}$ wide and 9.30 - $14.50 \mathrm{~cm}$ long; simple, smooth, cordate in shape, green in colour, have entire margins; venation is reticulate, apices acuminate. Vines are $1.50-1.80 \mathrm{~cm}$ wide and 225-255 cm long; smooth, circular in shape and green in colour. Petiole is $25.30-31.30 \mathrm{~cm}$ long, root type is fibrous and storage. The orange fleshed (UMUSPO/3) variety is herbaceous and moderately spreading in habit, The phyllotaxy is Alternate; the leaves are $10.80-13.60 \mathrm{~cm}$ wide and 9.30 $14.50 \mathrm{~cm}$ long; smooth, cordate in shape, green with purple edge in colour, have entire margins; venation is reticulate, apices acuminate. Vines are $1.30-1.50 \mathrm{~cm}$ wide and $150-160 \mathrm{~cm}$ long; 
smooth, circular in shape and purple in colour. Petiole is 17.50 $20.30 \mathrm{~cm}$ long, root type is fibrous and storage. The result revealed some similarities and differences in the morphological characteristics between the varieties (Table1; Figures 1: (a-f). Similarities were observed in the habit, leaf type, colour, leaf arrangement, shape, margin, venation, apices, vine shape, texture and root type. Differences were observed in the vine length, vine colour, vine girth, leaf girth, leaf colour and petiole length. These similarities could be because they belong to the same species 'batatas'. The differences could be the reason for the different varieties. Qualitative and quantitative phenotypic morphology observed strengthens the intra and interspecific relationship and can be used for taxonomic decision. High variability among crop genotypes based on phenotypic characters has been reported by some authors (Aremu et al., 2007; Adewale et al., 2010 and Aziagba et al., 2016).

Table 1. Morphology of two varieties of Ipomoea batatas.

\begin{tabular}{lll}
\hline Features & White fleshed (TIS 87/0087) & Orange fleshed (umuspo/3) \\
\hline Plant Type & Herbaceous & Herbaceous \\
Growth Habit & Extremely Spreading & Moderate Spreading \\
Phyllotaxy & Alternate & Alternate \\
Leaf Length & $9.30-14.50 \mathrm{~cm}$ & $9.30-14.50 \mathrm{~cm}$ \\
Leaf width & $10.60-14.30 \mathrm{~cm}$ & $10.80-13.60 \mathrm{~cm}$ \\
Leaf Type & Simple & Simple \\
Leaf Texture & Smooth & Smooth \\
Leaf Shape & Cordate & Cordate \\
Leaf Colour & Green & Green with Purple Edge \\
Leaf Margin & Entire & Entire \\
Leaf Venation & Reticulate & Reticulate \\
Leaf Apex & Acuminate & Acuminate \\
Vine width & $1.50-1.80 \mathrm{~cm}$ & $1.30-1.50 \mathrm{~cm}$ \\
Vine Length & $225-255 \mathrm{~cm}$ & $150-160 \mathrm{~cm}$ \\
Vine Texture & Smooth & Smooth \\
Vine Shape & Circular & Circular \\
Vine Colour & Green & Purple \\
Petiole Length & $25.30-31.30 \mathrm{~cm}$ & $17.50-20.30 \mathrm{~cm}$ \\
Root Type & Fibrous and Storage & Fibrous and Storage \\
\hline
\end{tabular}

Table 2. Nutritional compositions of orange fleshed and white fleshed sweet potato.

\begin{tabular}{|c|c|c|c|c|c|c|}
\hline \multirow{2}{*}{ Nutrients (\%) } & \multicolumn{3}{|c|}{ White fleshed } & \multicolumn{3}{|c|}{ Orange fleshed } \\
\hline & Leaf & Stem & Tuber & Leaf & Stem & Tuber \\
\hline Moisture content & $8.30 \pm 0.03^{b}$ & $6.84 \pm 0.06^{\mathrm{a}}$ & $10.35 \pm 0.08^{c}$ & $8.30 \pm 0.14^{b}$ & $6.87 \pm 0.07^{a}$ & $10.73 \pm 0.22^{d}$ \\
\hline Protein & $12.13 \pm 0.20^{c}$ & $6.91 \pm 0.10^{b}$ & $5.66 \pm 0.10^{a}$ & $8.89 \pm 6.58^{c}$ & $7.00 \pm 0.18^{b}$ & $5.27 \pm 0.39^{a}$ \\
\hline Crude fat & $3.92 \pm 0.14^{d}$ & $1.38 \pm 0.08^{b}$ & $1.19 \pm 0.03^{\mathrm{a}}$ & $3.82 \pm 0.10^{d}$ & $2.05 \pm 0.11^{\mathrm{c}}$ & $1.49 \pm 0.03^{b}$ \\
\hline Crude fibre & $14.11 \pm 0.16^{b}$ & $26.15 \pm 0.29^{d}$ & $2.57 \pm 0.12^{\mathrm{a}}$ & $14.06 \pm 0.07^{b}$ & $24.21 \pm 1.31^{c}$ & $2.45 \pm 0.03^{\mathrm{a}}$ \\
\hline Ash & $2.59 \pm 0.06^{d}$ & $1.37 \pm 0.06^{a}$ & $1.39 \pm 0.06^{\mathrm{a}}$ & $2.85 \pm 0.06^{\mathrm{e}}$ & $1.51 \pm 0.06^{\mathrm{b}}$ & $1.87 \pm 0.15^{c}$ \\
\hline $\mathrm{CHO}$ & $58.95 \pm 0.17^{a}$ & $57.58 \pm 0.44^{a}$ & $81.22 \pm 3.80^{c}$ & $61.82 \pm 7.22^{b}$ & $58.38 \pm 1.36^{a}$ & $78.79 \pm 0.30^{c}$ \\
\hline
\end{tabular}

Values are mean \pm standard deviation; Values with the same superscripts in the same row show no significant difference ( $p<0.05$ ).
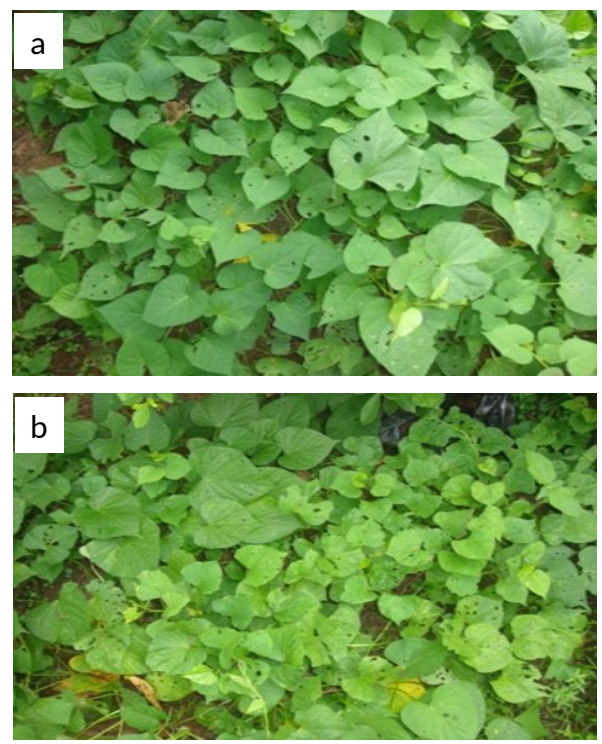
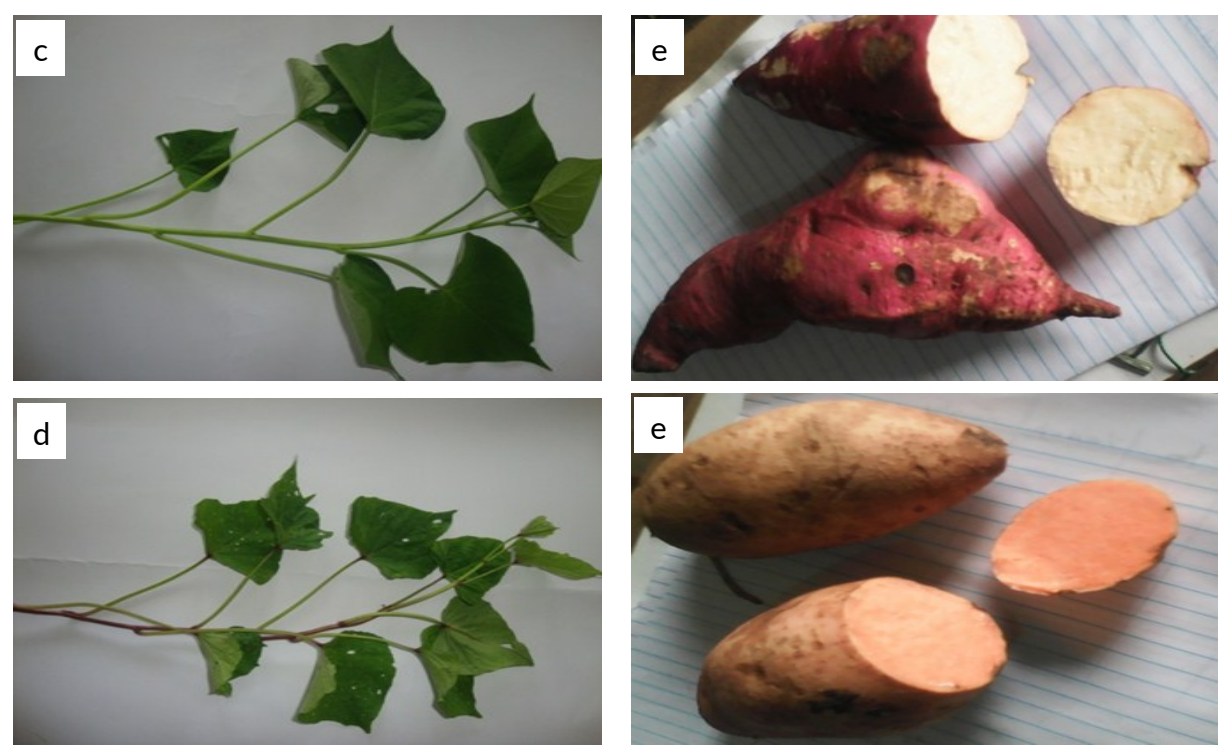

Figure 1: a. White fleshed variety in its natural habitat b: Orange fleshed variety in its natural habitat c: Twig of white fleshed variety d: Twig of orange fleshed variety $\mathrm{e}$ : Tubers of white fleshed variety f: Tubers of orange fleshed variety. 
Proximate studies

The research carried out on proximate analysis revealed that the nutrients were present in the parts investigated but in varied compositions (Table 2). This means that Ipomoea batatas has some nutritional potential that can be exploited in diet. The leaves, stems and tubers of both orange fleshed and white fleshed sweet potato revealed that moisture and carbohydrate contents were highest in the tubers when compared to other parts of the two varieties. Moisture content in white fleshed tuber $(10.35 \pm 0.08 \mathrm{mg} / 100 \mathrm{~g})$ orange fresh tuber $(10.73 \pm 0.22$ $\mathrm{mg} / 100 \mathrm{~g})$. Carbohydrate content in white fleshed tuber $(81.22 \pm 3.80 \mathrm{mg} / 100 \mathrm{~g})$ orange fleshed tuber $(78.79 \pm 0.30$ $\mathrm{mg} / 100 \mathrm{~g}$ ), (Table 1). The high content of carbohydrate in the tubers of both varieties makes them good sources of energy compared to other parts. The fresh roots (tubers) are commonly boiled, fried or roasted and eaten as a carbohydrate constituent of the diet (Zuraida, 2003). The high moisture content in the tubers of the two varieties indicated that the tubers are more prone to deterioration since food with high moisture contents are prone to perishability (Ilodibia et al., 2014). Protein, fat and ash contents were highest in the leaves when compared to other parts of the two varieties. Protein content in white fleshed leaf $(12.13 \pm 0.20 \mathrm{mg} / 100 \mathrm{~g})$ orange fleshed leaf $(8.89 \pm 6.58 \mathrm{mg} / 100 \mathrm{~g})$. Fat content in white fleshed leaf $(3.92 \pm 0.14 \mathrm{mg} / 100 \mathrm{~g})$ orange fleshed leaf $(3.82 \pm 0.10 \mathrm{mg} / 100 \mathrm{~g})$. Ash content in white fleshed leaf $(2.59 \pm 0.06 \mathrm{mg} / 100 \mathrm{~g})$ orange fleshed leaf $(2.85 \pm 0.06$ $\mathrm{mg} / 100 \mathrm{~g}$ ) (Table 2).The high content of crude protein in the leaves of both varieties indicated that sweet potato leaves are good source of protein and therefore could be recommended as good food for alleviating protein-energetic malnutrition (Sanoussi et al., 2016). The high content of fat obtained showed that the leaves of the two varieties are more palatable because dietary fats function to increase food palatability by absorbing and retaining the flavors. The high ash content in the leaves of both varieties indicated that these varieties are rich in some mineral salt which could be promoted for preventing and curing hidden hunger especially among children, pregnant and lactating women. Also, dietary ash has proved helpful in establishing and maintaining acid-alkaline balance of the blood system (Ilodibia et al., 2014). Crude fibre content was highest in the stem when compared to other parts of the two varieties, although the nutrient was higher in the white fleshed than orange fleshed. Crude fibre content in white fleshed stem $(26.15 \pm 0.29 \mathrm{mg} / 100 \mathrm{~g})$ orange fleshed stem $(24.21 \pm 1.31$ $\mathrm{mg} / 100 \mathrm{~g}$ ) (Table 2). The high composition of crude fibre in the stem of both varieties indicated that they could be more digestible when used as a feed for farm animals (Ilodibia et al., 2017a). According to Trinidad (2013), dietary fibers are important in preventing cardiovascular diseases and diabetes mellitus and they are also efficient in reducing the incidences of colon cancer and certain digestive diseases (Ingabire and Hilda, 2011). The result is in line with the works of (Ilodibia et al., 2016a, b; llodibia et al., 2017b) who reported similar results among various parts of Celosia argentea, Gomphrena celosioides and Abelmoschus esculentus.
Conclusion

Data obtained indicated that these parts of the two varieties contained appreciable amount of nutrients which could be included in diets to supplement our daily nutrient needs and animal feed. Apart from the tuber eaten by our people, other parts of the plant should also be used as food. Overall data could be a viable tool for sweet potato breeding as an improvement in sweet potato production. Morphological characteristics observed were similar and consistent indicating that the two varieties are phyllogenetically related. The data could also be used to enhance proper taxonomic characterization and identification of the species I. batatas.

\section{ACKNOWLEDGEMENTS}

This work was carried out in collaboration between all authors. Author CVI designed the study and wrote the protocol. All Authors wrote the first draft of the manuscript. All Authors managed the analyses of the study and the literature searches. All authors read and approved the final manuscript.

\section{Conflict of interest}

Authors have declared that no competing interests exist.

Open Access: This is an open access article distributed under the terms of the Creative Commons Attribution 4.0 License, which permits unrestricted use, distribution, and reproduction in any medium, provided the original author(s) if the sources are credited.

\section{REFERENCES}

Adepoju, A.L. and Adejumo, B.A. (2015). Some Proximate Properties of Sweet Potato (Ipomoea Batatas L) As Influenced By Cooking Methods. International Journal of Scientific \& Technology Research, 4 (3):146-148.

Adewale, B.D., Okonji, C., Oyekanmi, A.A., Akintobi, D.A.C. and Aremu, C.O. (2010). Genotypic variability and stability of some grain yield components of cowpea. African Journal of Agricultural Resource, 5: 874-880.

AOAC. (2005). Official Method of Analytical Chemistry, Washington DC; pp. 235.

Aremu, C.O., Ariyo, O.J. and Adewale, B.D. (2007). Assessment of selection techniques in genotype $X$ environment interaction in cowpea Vigna unguiculata (.L.) Walp. African Journal of Agricultural Resource, 2: 352-355.

Austin, D.F. (1977). Hybrid Polyploids in Ipomoea Section batatas. Journal Heredity, 68:259-260.

Austin, D.F. and Huáman, Z. (1996). A synopsis of Ipomoea (Convolvulaceae) in the Americas. Taxon, 45: 3-38.

Aziagba, B.O., Okeke, C.U., Ezeabara, C.A., Ilodibia, C.V. and Obika, I.E. (2016).Taxonomic Implication of Morphology of Seven Varieties of Vigna unguiculata (L.) Walp. Cultivated in Awka, Anambra State, South Eastern Nigeria. America Journal of Life Science Researches 4(4): 132-137 
Bhattiprolu, S. (2000). Color, Texture and Rehydration Characteristics of Ohmically Treated Sweet Potatoes. A Thesis Submitted to the Graduate Faculty of the Louisiana State University and Agricultural And Mechanical College, Louisiana.

Cao, S., Wisse, G.J.H., Miller, J.S., Evans, R. and Kingston, D.G.I. (2005). Ipomoeassins A-E, cytotoxic macrocyclic glicoresins from the leaves of Ipomoea squamosa from the Suriname rainforest. Journal National Production, 68: 487-492.

Chukwu, O., Nwadike, N. and Nwachukwu, N.G. (2012). Effect of cooking and frying on antioxidants present in sweet potato (Ipomoea batatas). Academic Research International, 2(2): 1-5.

Dzomeku, B.M., Armo-Annor, F., Adjei- Gyan, K. and Darkey, S.K. (2007). Consumer preference for three selected Musa hybrids in Ghana. American Journal of Food Technology, 2: 684-688.

Effah-Manu, L., Oduro, I. and Addo, A. (2013). Effect of Dextrinized Sweet potatoes on the Physicochemical and Sensory. Journal of Food Processing and Technology, 4:5.

Heuzé V., Tran G., Hassoun P., Renaudeau D. and Bastianelli D. (2015). Sweet potato (Ipomoea batatas) tubers. Feedipedia, a programme by INRA, CIRAD, AFZ and FAO. Retrieved from: https://www.feedipedia.org/node/745

Ilodibia, C.V., Achebe, U.A. and Chiafor, C. (2017b). Nutrient characteristics assessment of two variants of okra (Abelmoschus esculentus L. Moench.) found in Anambra State, Nigeria. Archives of Agriculture and Environmental Science. 2(4): 298-300

Ilodibia, C.V., Chukwuka, C., Chukwuma, M.U., Akachukwu, E.E., Igboabuchi, N.A. and Adimonyemma, R.N. (2016a). Proximate composition, vitamin and anatomical studies on Celosia argentea. British Biotechnology Journal, 15(4): 1-7.

Ilodibia, C.V., Ewere, F.U., Akachukwu, E.E., Adimonyemma, R.N., Igboabuchi, N. A. and Okeke, N.F. (2016b). Proximate composition, vitamin and anatomical studies on Gomphrena celosioides. Annual Research and Review in Biology, 10(3): 1-6. Ilodibia, C.V., Nnaji, E., Aziagba, B.O. and Ezeabara, C.A. (2017a). Morphological and nutritional assessment of leaf, stem and root of Zanthoxylum macrophylla (Rutaceae). Archives of Agriculture and Environmental Science. 2(1): 44-46

Ilodibia, C.V., Ugwu, R.U., Okeke, C.U., Ezeabara, C. A., Okeke, N. F., Akachukwu, E.E. and Aziagba, B.O. (2014). Determination of proximate composition for various parts of two
Dracaena species. International Journal of Botany, 10: 37-41. Ingabire, M.R and Hilda, V. (2011). Comparison of the nutrient composition of four sweet potato varieties cultivated in Rwanda. American Journal of Food and Nutrition, 1(1):34-38

Janssens, M. (2001). Sweet Potato In: Raemaekers RH. Crop Production in Tropical Africa. CIP Royal Library Albert I, Brussels, pp. 205-221.

Jones, A. (1965). Cytological Observations and Fertility Measurements of Sweet Potato [Ipomoea batatas (L.) Lam]. Proceedings of the American Society of Horticultural Science, 86: 527-537.

Kure, O.A., Nwankwo, L. and Wyasu, G. (2012). Production and quality evaluation of garri- like product from sweet potatoes. Journal Natural Production and Plant Resources, 2 (2):318-321.

Longe, O.G. (1986). Energy Content of some tropical starch crop in Nigeria. Journal of Agriculture, 21: 134-136.

Okorie, S.U. and Onyeneke, E.N. (2012). Production and Quality Evaluation of Baked Cake from Blend of Sweet Potatoes and Wheat Flour. Journal of Natural and Applied Science, 3 (2): 110.

Parle, M. and Monika, A. (2015). Sweet potato as a super-food. International Journal Research Ayurveda Pharm, 6(4): 557562.

Sanoussi, A.F., Adjatin, A., Dansi, A., Adebowale, A., Sanni, L.O. and Sanni, A. (2016). Mineral Composition of Ten Elites Sweet Potato (Ipomoea Batatas [L] Lam) Landraces of Benin. International Journal of Current Microbiology and Applied Science, 5(1): 103-115.

Trinidad, P.T., Sagum, R.S., Mallillin, A.C., Borlagdan, M.S., De Leon, M.P. and Aviles, T. (2013). Sweet Potato and Cassava Can Modify Cholesterol Profile in Humans with Moderately Raised Serum Cholesterol Levels. Food Nutritional Science, 4 (5):491-495.

Wakjira, M., Adugna, D. and Berecha, G. (2011). Determining slice thickness of Banana (Musa spp.) for enclosed solar drying using solar cabinet dryer under Ethiopian condition. American Journal of Food Technology, 6:568- 580.

Woolfe, J.A. (1992). Sweet Potato: An untapped Food Resource. Cambridge University Press, Cambridge, U.K, pp. 389.

Zuraida, N. (2003). Sweet Potato as an Alternative Food Supplement during Rice Shortage. Journal Litbang Pertanian, 22: 150- 155. 